\title{
Ethnoveterinary Practices in Villupuram District, Tamil Nadu, India
}

\author{
S. Dhanam ${ }^{1, *}$, B. Elayaraj ${ }^{2}$ \\ ${ }^{1} \mathrm{PG}$ and Research Department of Botany, Arignar Anna Government Arts College, \\ Villupuram - 605 602, Tamil Nadu, India \\ ${ }^{2}$ Department of Botany, Annamalai University, Annamalai Nagar - 608 002, Tamil Nadu, India \\ *E-mail address: sdhanam2@gmail.com
}

\begin{abstract}
Ayurvedic medicines are considered to be the best systems of treatment in India and this system is spreading now globally. Natural products are also a part of our everyday life. Ethno veterinary medicine is developed by farmers in field and barns rather than and in scientific laboratories. It is less systematic, less formalized and usually transferred by word of mouth rather than writing. An ethnobotanical survey was conducted in 10 selected sites of Villupuram district. Twenty six plant species belonging to fourteen families were documented in the present study, to cure different diseases in animals. Interviews and detailed personal discussions were conducted with the traditional healers and local people to identify the plants and their medicinal information for six months. The study revealed that the different parts of these plants were used for treatment of different diseases. Leaves are the mostly used part to prepare medicine.
\end{abstract}

Keywords: Ayurvedic medicine; Ethnoveterinary; Traditional knowledge; Villupuram District

\section{INTRODUCTION}

Plants are vital for existence of life on earth. The plants around the habitats of the rural population not only provide food for living organisms, but also provide different chemicals for human health. Large populations in India still rely on traditional herbal medicine (Dubey et al., 2004). In India it is reported that traditional healers use 2500 plant species and 100 species of plants serve as regular sources of medicine (Pei, 2001). Ethnobotanical knowledge has been documented from various parts of the Indian sub-continent (Das and Tag 2006; Udhyan et al., 2005). Several medicinal herbs are flourishing in the state which has been in constant use by local inhabitants in serving to cure the ailments of livestock (Bharathi Kumar et al., 2009; Balakrishnan et al., 2009).

Since the last three to four decades considerable progress has been made in the field of ethnobotany due to recent explorations. Recently it has been realized that certain medicinal plants are going to play a very significant role in ethnoveterinary practices. Ethno veterinary medicines include the indigenous belief, knowledge, skills, methods and practice pertaining to the health care of animals (Bhatt et al., 2013). These medicines are affordable, more effective, easily available and also able to fulfill the social and cultural needs of the rural, aboriginal and tribal people. The data generated by this study will be helpful for making the 
maximum and sustainable use of plants as well as animal resources. The disappearance of these practices will not only affect poor villagers and their livestock but also be a permanent loss of our culture, heritage and biodiversity. So, attempt was made on the survey of ethno veterinary practices in certain villages of Villupuram district, Tamil Nadu. The study focuses pathogenic diseases, digestive disorders and reproductive problems associated with livestock might be overcome by folklore medicines derived from one or combination of several plants.

\section{MATERIALS AND METHODS}

The present research work has been carried to find out the ethnoveterinary medicine of certain villages in Villupuram district of Tamil Nadu.

\section{Study area}

Villupuram district in situated near by Bay of Bengal. Villupuram district is surrounding by Cuddalore district in East, Thiruvannamalai district in west, Perambalur district in south and Kanchipuram district in north. Field trips were conducted to different villages of Villupuram district such as Saalai, Kayathur, Vaniyampalayam, Koliyanur, Radhapuram, Avadaiyarpet, Reddikuppam, Ettikkadu, Athanoor and Ganapathipet.

\section{Plant collection}

Information about the ethnic uses of plants were collected from native medicine man, age olders, Siddha doctors and various know ledged peoples about Siddha medicine. The information were collected through oral interviews and recorded. The plants were collected and verified using Gamble flora (Gamble, 1967) and also verified used standard herbarium.

\section{RESULTS AND DISCUSSION}

A total of 26 medicinal plant species distributed were collected from the study area with the help of traditional healers. Medicinal plants used by them are given with botanical name, family, common name, local name, animal name, animal condition, useful parts, mode of preparation and medicinal uses.

\begin{tabular}{|l|l|l|}
\hline Botanical Name & Cissus quadrangularis L. & Calotropis gigantea (L.) R. Br. \\
\hline Family & Vitaceae & Asclepiataceae \\
\hline Local Name & Pirandai & Erukku \\
\hline Animal Name & Dog & Dog \\
\hline Animal Condition & Bone fracture & Wounds \\
\hline Useful part & Stem & Whole plant \\
\hline $\begin{array}{l}\text { Mode of preparation } \\
\text { and medicinal uses }\end{array}$ & $\begin{array}{l}\text { Paste or alcoholic extract of this plant } \\
\text { stem were used locally as well as } \\
\text { intramuscularly facilities rapid healing } \\
\text { of fractured bone in dogs. }\end{array}$ & $\begin{array}{l}\text { Whole plant parts are crushed and the } \\
\text { latex is aplied to the wounds. }\end{array}$ \\
\hline
\end{tabular}




\begin{tabular}{|l|l|l|}
\hline Botanical Name & Datura metal auct, non L. & Curcuma longa auct, non L. \\
\hline Family & Solanaceae & Zingiberaceae \\
\hline Local Name & Oomathai & Manjal \\
\hline Animal Name & Cat & Cat \\
\hline Animal Condition & Wounds in leg & Wounds \\
\hline Useful part & Leaves & Rhizome \\
\hline $\begin{array}{l}\text { Mode of preparation } \\
\text { and medicinal uses }\end{array}$ & $\begin{array}{l}\text { Fresh leaves are ground and applied } \\
\text { for wounds in cat leg. }\end{array}$ & $\begin{array}{l}\text { The dried rhizome is ground with the } \\
\text { help of water and made into a paste. } \\
\text { This paste is given to swallow. }\end{array}$ \\
\hline
\end{tabular}

\begin{tabular}{|l|l|l|}
\hline Botanical Name & Arachis hypogeae L. & Aloe vera (L.) Burn. F \\
\hline Family & Fabaceae & Liliaceae \\
\hline Local Name & Manila or Nilakkadalai & Sotrukatrazhal \\
\hline Animal Name & Cow & Cow \\
\hline Animal Condition & Infertility in cow & Wounds \\
\hline Useful part & Seed & Leaves \\
\hline $\begin{array}{l}\text { Mode of preparation } \\
\text { and medicinal uses }\end{array}$ & $\begin{array}{l}\text { The raw nuts are ground with fresh } \\
\text { milk. This mixer is drenched to cow } \\
\text { once a day, for 3-5 days. }\end{array}$ & $\begin{array}{l}\text { Break a piece of a leaf of Aloe vera. So, } \\
\text { that the sap begins to trip. Apply the sap } \\
\text { on the wound. The left itself can also be } \\
\text { crushed and applied. }\end{array}$ \\
\hline
\end{tabular}

\begin{tabular}{|l|l|l|}
\hline Botanical Name & Ricinus communis L. & Musa paradisiaca L. \\
\hline Family & Euphobiaceae & Musaceae \\
\hline Local Name & Aamanakku & Vaazhai \\
\hline Animal Name & Cow & Cow \\
\hline Animal Condition & Wound & Worms \\
\hline Useful part & Seed & Root \\
\hline $\begin{array}{l}\text { Mode of preparation } \\
\text { and medicinal uses }\end{array}$ & $\begin{array}{l}\text { and boil them to make oil. Dry leaves } \\
\text { can also be used after being crushed } \\
\text { into a powder. Apply the oil or the leaf } \\
\text { powder on the wound, completely } \\
\text { covering the wound until it heals. }\end{array}$ & The root juice is given to swallow. \\
\hline
\end{tabular}

\begin{tabular}{|l|l|l|}
\hline Botanical Name & Allium sativam L. & Vitex negundo L. \\
\hline Family & Liliaceae & Verbenaceae \\
\hline Local Name & Poondu & Nochi \\
\hline Animal Name & Goat and Cattle & Cattle \\
\hline Animal Condition & Gastrieis & Body pain and cough \\
\hline Useful part & Rhizome & Leaves \\
\hline $\begin{array}{l}\text { Mode of preparation } \\
\text { and medicinal uses }\end{array}$ & $\begin{array}{l}\text { Paste of bulb is given two times a day } \\
\text { for gastric stimulant in cattle and goat. }\end{array}$ & $\begin{array}{l}\text { Decoction of leaf is given two times a } \\
\text { day for body pain and cough to cattle. }\end{array}$ \\
\hline
\end{tabular}




\begin{tabular}{|l|l|l|}
\hline Botanical Name & Lippie nodiflora (L.) A. Rich & Datura stramonium L. \\
\hline Family & Verbenaceae & Solanaceae \\
\hline Local Name & Poduthalai & Kuru oomathai \\
\hline Animal Name & Goat and Cattle & Cattle \\
\hline Animal Condition & Anorexia and digestion & Eye diseases \\
\hline Useful part & Leaves & Leaves \\
\hline $\begin{array}{l}\text { Mode of preparation } \\
\text { and medicinal uses }\end{array}$ & $\begin{array}{l}\text { Leaf decoction is given one time, three } \\
\text { days for anorexia and digestion to goat } \\
\text { and cattle. }\end{array}$ & $\begin{array}{l}\text { Juice of leaf is applied to eye diseases } \\
\text { in cattle. }\end{array}$ \\
\hline
\end{tabular}

\begin{tabular}{|l|l|l|}
\hline Botanical Name & Euphobia hirta L. & Ficus bengalensis L. \\
\hline Family & Euphorbiaceae & Moraceae \\
\hline Local Name & Ammaan patcharisi & Aalamaram \\
\hline Animal Name & Cattle & Goat \\
\hline Animal Condition & Heamorrhagic enteritis & Bone fracture \\
\hline Useful part & Whole plant & Leaves \\
\hline $\begin{array}{l}\text { Mode of preparation } \\
\text { and medicinal uses }\end{array}$ & $\begin{array}{l}\text { Juice of whole plant is given two times } \\
\text { a day for heamorrhagic }\end{array}$ & $\begin{array}{l}\text { Paste of leaf is applied externally for } \\
\text { bone fracture to goat. }\end{array}$ \\
\hline
\end{tabular}

\begin{tabular}{|l|l|l|}
\hline Botanical Name & Curcuma aromatica Salisb. & Bambusa arundinacea (Retz.) Wild. \\
\hline Family & Zingiberaceae & Poaceae \\
\hline Local Name & Kasthuri manjal & Moongil \\
\hline Animal Name & Cow & Cow \\
\hline Animal Condition & Inflammation of the udder (Mastitis) & Diarrhea \\
\hline Useful part & Rhizome & Leaves \\
\hline $\begin{array}{l}\text { Mode of preparation } \\
\text { and medicinal uses }\end{array}$ & $\begin{array}{l}\text { Add water to ground dried rhizome } \\
\text { and applied to the inflammation of the } \\
\text { udder (Mastitis) in cow. }\end{array}$ & $\begin{array}{l}\text { Leaf is given internally for diarrhea in } \\
\text { cow. }\end{array}$ \\
\hline
\end{tabular}

\begin{tabular}{|l|l|l|}
\hline Botanical Name & Acorus calamus L. & Vitex negundo L. \\
\hline Family & Araceae & Verbenaceae \\
\hline Local Name & Vasambu & Nochi \\
\hline Animal Name & Hen & Hen \\
\hline Animal Condition & Ectoparasitic & Ectoparasitic \\
\hline Useful part & Whole plant & Leaves \\
\hline $\begin{array}{l}\text { Mode of preparation } \\
\text { and medicinal uses }\end{array}$ & $\begin{array}{l}\text { Acorus calamus is ground and then } \\
\text { applied over the affected area of the } \\
\text { skin in hen }\end{array}$ & $\begin{array}{l}\text { Smoke of notchi leaf is to control the } \\
\text { ectoparasities. }\end{array}$ \\
\hline
\end{tabular}




\begin{tabular}{|l|l|l|}
\hline Botanical Name & Allium cepa L. & Eclipta alba L. \\
\hline Family & Liliaceae & Euphobiaceae \\
\hline Local Name & Venkayam & Karisalankanni \\
\hline Animal Name & Hen & Rabbit \\
\hline Animal Condition & Parasite and fever & Skin diseases \\
\hline Useful part & Rhizome & Leaves \\
\hline $\begin{array}{l}\text { Mode of preparation } \\
\text { and medicinal uses }\end{array}$ & $\begin{array}{l}\text { Fresh onion stem are given internally } \\
\text { for parasites or fever to hen. }\end{array}$ & $\begin{array}{l}\text { Fresh leaves are ground and applied to } \\
\text { the skin disease in rabbit. }\end{array}$ \\
\hline
\end{tabular}

\begin{tabular}{|l|l|l|}
\hline Botanical Name & Aloe vera L. & Musa paradisiaca L. \\
\hline Family & Liliaceae & Musaceae \\
\hline Local Name & Sotrukkatrazhai & Vaazhai \\
\hline Animal Name & Cow & Buffalo \\
\hline Animal Condition & Stomach wound & Foot mouth disease \\
\hline Useful part & Leaves & Fruit \\
\hline $\begin{array}{l}\text { Mode of preparation } \\
\text { and medicinal uses }\end{array}$ & $\begin{array}{l}\text { Fresh leaves were taken and remove } \\
\text { the epidermal layer and the inner core } \\
\text { of fluid applied to cure the stomach } \\
\text { wound in cow. }\end{array}$ & $\begin{array}{l}\text { Fresh fruit are given internally for foot } \\
\text { mouth disease in buffalo. }\end{array}$ \\
\hline
\end{tabular}

\begin{tabular}{|l|l|l|}
\hline Botanical Name & Azadiracta indica Adr. Juss. & Phyllanthus niruri L. \\
\hline Family & Meliaceae & Euphobiaceae \\
\hline Local Name & Vembu & Keelanelli \\
\hline Animal Name & Cow & Sheep \\
\hline Animal Condition & Foot mouth disease & Cough and fever \\
\hline Useful part & Seed & Root \\
\hline $\begin{array}{l}\text { Mode of preparation } \\
\text { and medicinal uses }\end{array}$ & $\begin{array}{l}\text { Dried seed is ground to oil and add } \\
\text { camphor and applied to the foot } \\
\text { comary in cow }\end{array}$ & $\begin{array}{l}\text { Decoction of root is given in two times } \\
\text { a day to cure cough and fever. }\end{array}$ \\
\hline
\end{tabular}

\begin{tabular}{|l|l|l|}
\hline Botanical Name & Ocimum sanctum L. & Solanum nigrum L. \\
\hline Family & Lamiaceae & Solanaceae \\
\hline Local Name & Thulasi & Manathakkali \\
\hline Animal Name & Cattle & Cattle \\
\hline Animal Condition & Snake bite & Ulcer \\
\hline Useful part & Leaves & Leaves \\
\hline $\begin{array}{l}\text { Mode of preparation } \\
\text { and medicinal uses }\end{array}$ & $\begin{array}{l}\text { Paste of entire plant is given orally } \\
\text { twice a day for three days to snake } \\
\text { bites in cattle. }\end{array}$ & $\begin{array}{l}\text { Leaf paste is given orally twice a day } \\
\text { for three days to ulcer in cattle. }\end{array}$ \\
\hline
\end{tabular}

The present study revealed that twenty six plant species belonging to fourteen families are found in the different areas of Villupuram district. The listed plants possess medicinal values and were used mostly to cure different livestock diseases and or ailments like diarrhoea, mouth diseases, indigestion, wounds, bone fracture, dermatitis and poisonous bites etc. The data evidence that four species of Liliaceae, four species of Euphorbiaceae, three species of Verbinaceae, three species of Solanaceae two species of Zingiberaceae, two species of Musaceae followed by one species of Vitaceae, Asclepiadiaceae, Fabaceae, 
Moraceae, Poaceae, Araceae, Meliaceae and Lamiaceae were employed for preparation of herbal remedies for curing animal diseases.

The usage of Piper nigrum and Allium cepa was very common for curing eye diseases, indigestion, constipation, wounds (Tiwari and Pande, 2010) insect problems (Saikia and Borthakur, 2010) and fever (Nag et al., 2007) was in traditional practice of animal care in Uttarkand, Assam and Rajasthan. Similarly, plant species of Zingiber officinalis, Curcuma domestica (Tiwari and Pande, 2010) Azadirachta indica, Datura metel (Sanyasi Rao et al., 2008) Calotropis procera (Kiruba et al., 2006) withania somnifera, Corallacarpus epigaeus, Bambusa arundinacea (Ganesan et al., 2008) Sesamum indicum, Tridax procumbens and Wrightia tinctoria (Nag et al., 2007) were reported to have ethnoveterinary medicinal values in many places of India. Further study and promotion of ethnoveterinary medicine is bound to help the communities conserve information and integrate select practices into rural animal healthcare services.

\section{CONCLUSION}

The findings of this study may become basic leads for chemical, pharmacological, clinical and biochemical investigations. These observations would serve as data base to formulate plant derived compounds in herbal veterinary drugs which could serve as better alternative to allopathic medicines that cause side effects in liverstock. The study focuses the adoption of folk medicines for immediate action on animal care along with liverstock related social realities. Local people and the keepers of this knowledge should be recognized and appropriately compensated.

\section{References}

[1] Balakrishnan V., J. Philip Robinson, A. Manickasamy, K. C. Ravindran, Global Journal of Pharmacology 3(1) (2009) 15-23.

[2] Bharati Kumar, Avinash Bharati and B. L. Sharma. The Indian forester 135(5) (2009) 691-696.

[3] Bhatt A., P. Singh, V. Kumarm M. Baunthiyal. Journal of Environ. Nanotechnol. 2 (2013) 22-29.

[4] Das A., H. Tag. Indian Journal of Traditional Knowledge 5(3) (2006) 317-322.

[5] Dubey N. K., R. Kumar, P. Tripati. Current Science 86(1) (2004) 37-41bhatt

[6] Gamble J. S., Flora of the presidency of Madras, Botanical Survey of India, Calcutta. (1967)

[7] Ganesan S., M. Chandhirasekaran, A. Selvaraj, Indian Journal of Traditional Knowledge 7 (2008) 347-354.

[8] Kiruba S., S. Jeeva and S. S. M. Dhas, Indian Journal of Traditional Knowledge 5 (2006) 575-578.

[9] Nag A., P. Galav, S. S. Katewa, Indian Journal of Traditional Knowledge 6 (2007) 583-588. 
[10] Pei., Pharma Bio. 39 (2001) 74-79.

[11] Saikia B., S. K. Borthakur, Indian Journal of Traditional Knowledge 9 (2010) 49-51.

[12] Sanyasi Rao M. L., Y. N. R. Varma Vijayakumar, Ethnobotanical Leaflets 12 (2008) 217-226.

[13] Tiwari L., P. C. Pande, Indian Journal of Traditional Knowledge 9 (2010) 611-617.

[14] Udhyan P. S., Sateesh George, K. V. Thushar, Indira Balachandran, Indian Journal of Traditional Knowledge 4(4) (2005) 437-442.

[15] S. Dhanam, International Letters of Natural Sciences 11(2) (2014) 197-208.

[16] S. Dhanam, B. Elayaraj, International Letters of Natural Sciences 14 (2014) 1-10.

[17] Musharaf Khan, Abdurehman, Farrukh Hussain, Zabta Khan Shinwari, Shahana Musharaf, International Letters of Natural Sciences 15(2) (2014) 190-197. 